\title{
Strategic Leadership in Post-Conflict States: A Study of the Democratic Republic of Congo (DRC)
}

\author{
Louis Muzinga Mukonga ${ }^{1}$, Olawumi D. Awolusi ${ }^{2}$ \\ ${ }^{1}$ University of Roehampton, London, UK \\ ${ }^{2}$ Kampala International University, Kampala, Uganda \\ louis.muzinga@roehampton-online.ac.uk, awolusi.olawumi@kiu.ac.ug
}

\begin{abstract}
The research examines the impact of strategic leadership in post-conflict states. This was achieved by comparing different leadership styles with the performance of the post-conflict state to identify which leadership style fits best with specific performance indicators in The Democratic Republic of Congo (DRC). The study explores the qualitative methodology to assess the impact of strategic leadership in post-conflict states through an explanatory view using an interpretive approach, participant contributions, direct observations, documents, and interviews. Data were analyzed using NVivo data analysis software. The research discovered leadership deficiency at all levels of society. The leadership lacks some essential characteristics to guarantee the well-being of the people. The study also observed an inadequate commitment to support the vision. Also, the mismanagement of country natural resources often causes insecurity and triggers the creation of many armed groups to exploit the resources illegally. The study, therefore, recommended strong committed leadership, the political will, and stable state institutions. One needs a committed leadership to set the vision which can make a change in people's lives, and we can gain the milestones and eventually achieve the vision with the support of the political will and stable state institutions. The study contributes to knowledge by developing a much more user-friendly formula that summarizes the strategic, leadership needed in post-conflict states.
\end{abstract}

Keywords: Strategic leadership; performance; post-conflict states; qualitative methodology; the Democratic Republic of Congo (DRC).

\section{Introduction}

The DRC is potentially rich in natural resources, while its people continue to endure suffering and live in extreme poverty. The people do not enjoy the wealth that the country possesses due to inequality of profit sharing (USAID, 2018). This situation calls for a holistic approach to understand the reason behind this inconsistency. It is worth to note that the immense natural resources create jealousy and envy from the neighboring countries in the region. The mismanagement of these resources also fueled the situation and exposed the state to many internal disputes which eventually result in the formation of many rebel groups, militias, and also allow foreign incursions (Burnley, 2011). This holistic approach should not only look at the possibility to end violence but most importantly to address the genesis of the conflicts to lay down a robust foundation to ensure sustainable economic growth. The DRC conflicts don't only affect its development severely, but it also affects the entire region. Due to its strategic geopolitical importance, there is a need for high-level attention and a strong commitment by parties in the area (Africa) and the world to end these conflicts. Many African leaders have voiced their concerns about the DRC long-lasting conflicts. But it is sad to observe that there is no improvement simply.

Because leaders in the neighboring countries remain silent and take the opportunity of the prevailing situation to exploit DRC natural resources illegally (Brennan, 2010; Burnley, 2011). Great Lakes region member states who seem to be directly affected by the conflicts have tried to express their position to end the repeated cycle of conflicts and see how to strengthen peace in the region. Unfortunately, all those efforts failed to materialize once again because some states have direct interests, and consequently view the instability of the DRC as an excellent opportunity for their business to grow (Burnley, 2011). With this background, it is essential to increase awareness through systematic and meticulous approaches to better understand the real genesis of the conflicts in DRC, the impact on the country and regional development. In the end, it will help to make well-informed policy on sound decisions at all levels either national or international. The reason for the research is to find out the importance of strategic leadership in transforming the well-being of the Congolese society. In this study, we considered numbers of leadership styles for instance, transformational, transactional, democratic, visionary, and autocratic as independent variables and performance of a post-conflict state such as stable state institutions. 
Problem Statement: Since the country's independence in 1960, different governments have failed to meet the multiple demands of the Congolese people. The first president who took office after independence was Joseph Kasavubu. The systematic and analytical methods will complement one another to bring clarity to the nature of the conflicts, economic implications, human and social development. He failed to stabilize the country during the post-independence period, and in 1965 he was removed from power by Mobutu Sese Seko who also started his reign by giving people a lot of hope which most of them never materialized, and the country became vulnerable to corruption, scene of repression a complete failure of economic and social transformation (USIP, 2011). After more than thirty years in power, Mobutu is out and replaced by LaurentDesire Kabila in 1997. Kabila as his predecessor had an agenda for the country and also made promises to the people to improve their living conditions and restore peace and stability. Unfortunately, until he died in 2001, he did not manage to regain peace either stability as promised, and misery continued to ravage the lives of the citizen (USIP, 2011). President Joseph Kabila took power following the death of Laurent-Kabila.

He made promises to bring peace and reconstruct the country, but he is also facing challenges to bring peace to the nation in its entirety. We still observing continued violence in some parts of the DRC. The 2016 Kasai fighting, instability on the Angolan, the Ugandan and Rwandan border with occasional skirmishes reported from time to time. Since independence 1960, the country continues to be tormented by insecurity, poverty, corruption, and lack of leadership which leads to various governance challenges (Burnley, 2011). I decided to go more in-depth with analysis, and I discovered they are not primary causes of conflicts. Its institutions are weak, and all its commitment to build and restore durable peace and security in the country has not achieved intended objectives. Today, even some parts of the country known to be relatively calm have also experienced or still experiencing insecurity. The case of the Kasai province tormented by the presence of armed groups or militia known as "Kamuina Nsapu." Early this year 2018, the latest conflict has also erupted following a surge of ethnic violence in Djugu territory in Ituri Province located in the north-eastern part of the country leaving behind hundreds of people dead and nearly 50,000 people fled Congo to Uganda as refugees (Reuters, 2018).

Conflicts also persist in Beni and the general area of North and South Kivu Provinces both located to the East of the DRC. Those conflicts are believed to be perpetrated by militias who are at times a mixed of domestic and foreign armed groups. Also, mismanagement of DRC natural resources at some point still causing insecurity and instability in those regions and encouraged illegal exploitation of the resources (Burnley, 2011). Indeed, The DRC leadership lacks some elements of highest importance for the well-being of its people: Vision to lead the country into prosperity, the political will to accompany the vision, ability and expertise to accomplish the vision, and also, the quality and virtue required to ensure the achievement of the vision with fairness and impartiality, strict integrity and sound judgment. Finally, practitioners and a good number of scholars have all agreed in their studies that in DRC there is a leadership deficiency at all levels of the society. The nature of the conflicts in the DRC is resource induced conflicts (Burnley, 2011), hence, the necessity to identify those shortfalls and demonstrate how strategic leadership can be instrumental in the positive transformation of the Congolese society. Consequent upon the above problem, the main objective of the study was to analyze the role of strategic leadership in the performance of a post-conflict state; a review of the Democratic Republic of Congo. However, the following specific objectives were contrived:

a) To weight the importance of visionary leadership on the performance of a post-conflict state in the DRC.

b) To estimate the relationship that exists between transformational leadership and the performance of a post-conflict state in the DRC.

c) To access the connection between democratic leadership and the performance of a post-conflict state in the DRC.

d) To obtain the impact of autocratic leadership style on the performance of a post-conflict state in the DRC.

e) To know the value of transactional leadership vis a vis performance of a post-conflict state in the DRC.

To achieve the above objectives the following questions were asked:

a) What is the impact of autocratic leadership in the DRC security sector? 
b) What is the implication of the democratic leadership towards establishing stable state institutions in the DRC?

c) What is the role of transformational leadership in the fight against corruption in DRC?

d) What is the relationship between transactional leadership and poverty reduction in the DRC?

e) What is the relationship between visionary leadership and DRC economic development?

But, they are just logical consequences of the so-called primary reasons in the sense that the mismanagement of the natural resources sector and the subsequent unfair distribution of the revenues are the primary causes, of conflicts. In this context, instead of considering natural resources as direct causes of conflicts, the study shows the inability to implement both stable state institutions and active governing structure to handle those resources are the primary causes. Corruption, poverty reduction, security reform, economic development as dependent variables. Apart from the economic sector that has been affected, the DRC conflicts have had damaging effects on the human and social development viewpoint. Apart from many dead and population fleeing their home looking for refuge because of wars; conflicts have also caused an amount of psychological suffering for women, girls, and boys exposed to the various types of atrocities including rape, abduction, torture, disgrace, isolation from the society. Indeed, the impact of the wars has long-lasting wounds on people, groups, and the nation. It should be remembered after the cold war, even though strategic requirements might have altered, but the geographical position dictates that DRC continues to be strategically an essential player in the overall fight against terrorism. It is naturally known to be the centre of global natural resources that are highly needed by many corporates around the world. In this context, DRC must ensure stability and strengthen state authority over its territory. Therefore, the urgency for collective efforts at the national, regional and global arena is highly awaited to help the DRC leadership to ensure durable peace and sustainable economic development.

\section{Review of Related Literature}

Conceptual Review: In this study, "Leadership styles" has been identified as independent variables, "the performance of a post-conflict state," as the dependent variable, and "DRC" as the unit of analysis. Consequently, the imperative to define the following constructs:

Transformational Leadership: This leadership style aims at affecting changes regarding assumptions as well as attitudes to be held by members of an organization. It also builds the member's dedication to organizational objectives and its desired goals. With this type of leadership, communication plays a very significant role between managers and employees, and it is under the supervision of leaders that employees can achieve their goals and increase productivity as well as efficiency (Management Study HQ, 2018). In this regards a conceptual model has been developed to demonstrate their relationship to determine which leadership style is most appropriate that leaders need to be equipped with to be able to transform the wellbeing of the Congolese society.

Transactional Leadership: In transactional leadership, the leader pays employees in return for their outstanding performance. And for those who performed poorly can be punished. This leadership style might look patronizing and controlling, but it offers a range of benefits. On the one hand, it clearly defines the role and tasks for each staff members in the organization and offers compensation for the best performers. On the other hand, little is done by employees to improve job satisfaction; as a result, it may lead to an increased level of employee turnover. Since this leadership style is so limited concerning knowledge and workers creativity, it is better to consider it as good management techniques instead of a real leadership style as it targets short-term responsibilities only (LFHE, 2016).

Democratic Leadership: In this leadership style, team members are involved in decision making and provide their opinions. Then, leaders make the last decisions. This leadership style supports creative work and skill development; there is a tendency for an increased level of Job satisfaction by employees as they feel empowered. The downside of this style of leadership can delay response to situations where there is a need for immediate attention due to time spent in the process of collecting inputs from people. Also, some employees might not have the relevant expertise required to deliver a high-quality outcome (Iqbal et al., 2015). 
Visionary Leadership: These leaders have a persuasive vision, inspire and lead the people towards achieving the vision. Also, they impregnate the vision in their team members as well as the entire organization (Jeffrey, 2016). Also, they are neither dictatorial nor authoritarian. Instead, they are freedom providers so that employees can explore all the best opportunities to achieve the vision (Jeffrey, 2016).

Autocratic Leadership: Leaders give instructions and employees are expected to react with obedience and without arguing. Leadership takes decisions without consulting the group. In other words, autocratic leaders carry a lot of power over the groups (Iqbal et al., 2015). The team has insufficient opportunity to express their opinions even if these would benefit the organization. The advantage of autocratic leadership is that leaders can decide within the least amount of time and execute the task (Iqbal et al., 2015). This leadership style fits well in the army or dictatorial regime. The disadvantage is that people's opinions are underestimated and have no value. This may lead to absenteeism of personnel and high level of employee turnover. Nevertheless, this leadership style can be useful when dealing with unskilled jobs where employees are under control; in this case, it becomes an advantage as the value of the control is more significant than disadvantage (Iqbal et al., 2015).

Leadership Forms: As per Pavlov (2010), Charismatic, Conventional and coercive (3 Cs) are the three kinds of leadership (Pavlov's thoughts, 2010). The form constitutes the knowledge and skills that can be adjusted or changed merely depending on the level of the leader. Also, the form is known as the vehicle that provides managers and leaders with the ability to influence followers (Wilson learning, 2018). Coercive is the most used form of leadership to help structure the states, just because of their origin in class and ethnic conflict. Countries emphasize by forcing people to observe the laws and gain more massive domestic enforcement network (Pavlov's thoughts, 2010). Finally, Effective leadership is all about the Form and its Essence, the purpose for what one would like to become necessarily a leader, and the ability to carry out the required knowledge and skills. Corruption has a substantial effect on societies; it affects them on many fronts. In the worst-case scenario, we lose lives. Short of this, corruption costs people their well-being. It is only through the combination of Form and Essence a leader can successfully engage with followers to dedicate their energy, creativeness, and expertise for the success of the entire organization (Wilson learning, 2018).

Factors of Leadership: As per Kemps (2018), there are six factors of leadership effectiveness based on performance and expectations of the Job to be delivered. Here they are: (1) Initiate Trust and Exhibit Integrity: meaning correct display behavior and take the decision based on evidence, not rumors (2) Set a straightforward Direction: provide concise communication, involve others appropriately when making the direction, and ensure consistency and clarity when setting initiatives and goals. (3) Develop Relationships: promote open \& honest communication, encourage others contribution in planning or decision making, and also be proactive to fix relations that are damaged and seek to explain if there is any misinterpretation. (4) Attention on Results: Acknowledge team achievements regularly and celebrate accomplishment (5) Improve Capabilities: Give productive feedback through coaching as short-term task-based and mentoring as a longterm relationship (6) Promoting Innovation: willing to receive opposing views and perspectives (Kemps, 2018). Issues of leadership usually happen when there is a misrepresentation of the leader. Employees in most cases don't leave companies, but they go away from their managers who happen to have characters. Several studies have demonstrated that the most frequent reason why people leave the job is mostly related to the poor working relationship with their managers (Wilson learning, 2018).

Performance of a Post-Conflict State (Dependent Variables): Poor institutions impact negatively country economic growth and state policy implementation (Vanguard, 2018). However stable state institutions need the following structure to deliver effectively: The legislative chamber is accountable for endorsing state laws and has legal right to approve, disapprove or amend necessary bills to enable the government to operate, the executive branch is responsible for executing and managing the public policy endorsed and backed by the legislative chamber. The judicial branch is accountable for explaining the content of the constitution and the laws of the republic and applying their understandings to solve possible disagreements (NCSL, 2018). Corruption is considered "cancer that destroys the fabric of society" (Mansaray, 2009). Corruption is severely affecting the four sectors of the society: political, economic, social and environmental (Transparency International, 2018). The political sector, corruption is a significant barrier to the rule of law as well as to 
democracy. In democratic governance, state or private institutions lose their trust and legitimacy when they misuse for personal interest. In a corrupt environment, it is challenging to establish responsible political direction (Transparency International, 2018). The economic sector, corruption diminishes national prosperity. In a corrupt environment politicians fund projects with public resources that will benefit their pockets rather than looking at people interest, and leaders prioritize prestigious projects like the construction power plants, pipelines, refineries, and dams instead of focusing first on most needed.

Infrastructure projects like the construction of public hospitals, schools, roads, and markets. Also, corruption prevents the growth of equitable market structures and twists competition, and finally discourages investment (Transparency International, 2018). "The corruption kills the social fabric of society" (Mansaray, 2009). Corruption reduces the trust of the citizen in their leadership, institutions and the rest of the political apparatus. The environmental deterioration is another repercussion of corrupt structures. The lack of law enforcement to deal with environmental legislation and regulations on the legal exploitation of natural resources put the whole ecological systems at severe and immediate danger (Transparency International, 2018). Poverty reduction and the way to deal with remains a severe predicament of the discussions on global development and trade; it is essential to know that strategies on poverty reduction cannot achieve success if those strategies are not supported by strong policies to maintain rapid growth and enhance equal sharing of income (UNCTAD, 2015). The Eastern DRC has experienced a continuous deadly conflict that has taken away millions of lives and caused internally displaced persons and refugees' number to grow.

Also, this situation enables the rapid increase of rebel groups and militias. Unfortunately, this study has revealed that reforms are yet to happen in reorganizing the armed and police forces so that they can uphold territorial integrity, national sovereignty and guarantee the protection of people and their property. Some foreign partnerships to train and reshuffle all security forces are envisaged to keep the momentum. The DRC has enormous natural resources with the capacity to become one of Africa wealthiest countries. Nonetheless, the state is classified amongst the poorest nations on the planet, with GDP per capita income evaluated at $\$ 478$ US dollars in the International Monetary Fund's 2018 projected report (IMF, 2018). It is crucial to say that the poor performance of the DRC economy is the result of many years of corruption, embezzlement, and mismanagement of public funds, weak state institutions, unpredictable political atmosphere, and the wars (Global security, 2018). To turn the page, first, the DRC needs leadership which is ready to fight against corruption, impunity and other social inequalities. Then start improving and modernizing industries to strengthen the DRC economy.

Theoretical Review: This study agrees with Burns (1978) assumptions of Transformational Leadership Theory on the following grounds: The motivation of a senior moral position results in people following the leader. Also, collaborative work is by far better than individual action (Burns, 1978). It creates a healthy relationship which in turn produces a high level of trust and later on increases the motivation of the leaders as well as the followers. Burns is also of the view that transactional leadership is less efficient than transformational leadership. Transformational leadership is a method for strategic leaders, now in the context of this research; we consider a strategic leader to have the same characters and virtues as a transformational leader. They both build strong relationships with their followers by motivating them and increasing levels of morality. Both promote the work spirit of togetherness rather than an individual one. Also, this study agrees with Bass (1990) assumptions of Bass' Transformational Leadership on the following grounds.

The significance of the task motivates people; Bass also believed that a good focus on the team delivers a better Job at the end of the day (Bass, 1990). He further established ways in which leaders can be able to transform its followers: (1) initiate the follower's higher-order needs, (2) Followers need to be aware of the value and importance of task (Bass, 1990). About this research, it is evident that for change to happen leaders should communicate to followers their vision, clearly inform the value and importance of each task required to achieve desired goals. The study explained three leadership styles considered to be the most appropriate to deal with various performances: visionary, democratic and transformational leadership styles. First, visionary leaders set up the vision for long-term projects and guide people towards achieving desired goals. Second, with democratic leadership, the group is involved in the decisions making process and makes a good 
performance. And third, with transformational leadership, both sides motivate each other and expect excellent performance from each side (Iqbal et al., 2015).

Empirical Review: The DRC has a remarkable example to follow on the proper use of renewable resource management from some advanced economies as the case of Norway. This Nordic country has efficiently managed to use its macroeconomic tools to lead its national oil retention, revenues generated from oil exploitation and better revenue utilization by avoiding the possibly damaging effects of fair redistribution. In this manner, The Norwegian government has managed to stay away from the usual problems faced by an oilbased economy, for example, the wealth concentration and the boom and bust cycle. The DRC government and Norwegian government indeed differ in their transparency and accountability systems, but I believe Norway experience in this matter may serve as guidance to the DRC. Applying the Norway method together with accountability and transparency initiatives could help the DRC develop a better management system of non-renewable resources (Burnley, 2011). DRC conflicts have many roots moving around five aspects: internal or local elements, regional perspectives, global geopolitical aspects, economic aspects and institutional aspects. These aspects are so much interconnected one another to such an extent that one cannot treat them separately. If one needs to have a better understanding of the origin of the conflicts and how to address those challenges.

Since most conflicts are in the eastern DRC, certainly the human development, trade and economy in the Great Lakes Region are also affected as a result of the conflicts (UNECA, 2015). The expertise of the Diaspora cannot be underestimated as it has received considerable attention in the development of post-conflict states. In countries like Liberia, Rwanda, and Somalia, the members of the Diaspora are seen occupying senior management and leadership positions in the government, parliament, and senate. They are also present in top public or private enterprise positions. The Diaspora has been active in support of peace building, entrepreneurship, social, human, and economic development (Sheikh et al., 2009). The Diaspora community has the potential to contribute to the transformation of society (OECD, 2014). This study emphasizes the importance of strategic leadership and reveals some important tasks that the leaders can perform to transform the country from a chaotic situation into a prosperous nation. In summary, three leadership styles are believed to be the most appropriate for leaders to use in many contexts as they deliver outstanding performance in the long-term. Furthermore, Burns and Bass theories both demonstrated how transformational leadership is more effective than transactional leadership (Burns, 1978; Bass, 1990). Finally, the conceptual model also demonstrates the relationship between different leadership styles with the various performance of a post-conflict state.

\section{Methodology}

Research Method and Approach: The study has explored the problem using qualitative research methodology of the DRC case study. It is an explanatory view using an interpretive approach through participant contributions, direct observations, documents, and interviews. This method aims to ascertain the effectiveness of strategic leadership in transforming the well-being of Congolese citizen in the post-conflict environment. The qualitative methodology was based on a case study approach to learning more about the causes of the leadership deficiency in DRC which ultimately lead to poor governance and the way to address them. What the DRC needs to do to improve the management system and the subsequent transformation of the nation? What the state priorities are to rebuild the country in the post-conflict environment? And then come up with recommendations on how to answer those questions positively for the benefits of humanity (Sood, 2016).

Data Collection and Development and Administration of Research Instruments: The data collection source (case study) drew its origins from participant contributions or direct observations, audiovisual and archival materials, and interviews (Thompson, 2011). Using participant observation tools; the researcher had to travel to the DRC to carry out the research and spent a significant amount of time on the ground. During the process, we were involved in the situation together with other participants, and at the very same time, we had to record data or take notes of what we were observing. This technique tends to be mainly a qualitative method as it offers an opportunity to get a unique understanding of the subject in question. Indeed, it is productive, but we also discovered that there are some challenges associated with this technique as at the 
beginning we encountered difficulties in obtaining the access to some institutions, and also being accepted on the role to play within their organizational settings. It is also a time-consuming process (Lacono et al., 2009). As back up, the team used some spontaneous tools such as diaries or field notes to record data that we have managed to collect informally. These tools helped the team rapidly to document what we heard, seen or thought which might not be in the official recordings with the interviewees (Lacono et al., 2009). Some activities had taken place before we started the field works. These activities included creating awareness with involved stakeholders concerning the subject of the research in question, we invite voluntary participants, set time for interviews and set up organized storage for data management (Chandler et al., 2013).

During the meetings, the following criteria were observed: clarify study purpose, explain how discussion, as well as cooperation between the researcher and all possible participants, is important during this undertaking and specify interview projected duration (Chandler et al., 2013). Another important aspect, we have also managed to create an atmosphere where every participant is free to contribute, any opposing opinion is equally welcome on the table for further analysis. On one side participants were briefed on possible benefits they might receive, on the other side they were also briefed on the threat or potential risks that they might encounter during the research (Chandler et al., 2013). Also, once a participant has voluntarily accepted to be interviewed, we managed to secure a suitable place where the interview will take place with comfortable seating provisions, we also provided some light refreshments for interviewees comfort, finally, the team has ensured all equipment and materials needed are available for the smooth conduct of the interviews (Chandler et al., 2013).

Validity and Reliability Analysis: Previous studies have demonstrated that we can divide the loyalty of participant observation or interviews into measurement concepts: generalizability and classical test concepts (Awolusi, 2019; Awolusi \& Atiku, 2019). However, there are many ways to help control any errors that occurred with generalizability. One way to avoid is by duplicating the study of generalizability concept. For instance, we had two participant views of the same video, the team took notes of their observation, and we debated to obtain answers (Brennan, 2010). Also, using triangulation with many sources of data and participants, it helps to enhance dataset validity, and make sure the outcomes do not concern only one participant observation or just one group of the population, but the society (Carter et al., 2014). Additionally, we also discovered that observations that are supported by some video or audio recordings enriched data collection as one will be able to go through the records as many times as possible to make a review if needed from what was documented earlier (Brennan, 2010). Furthermore, piloting is an essential technique for focus team discussion; it allows problem identification in the topic guide concerning the words and the way to interpret specific questions, and areas that need additional field training techniques (Chandler et al., 2013).

Method of Data Analysis: Qualitative data analysis has begun when the fieldwork and management set up of the raw data information was completed. It is essential to know that this process can also be done simultaneously depending on what analytical method the project has decided to take. Indeed, data analysis programs under the qualitative methodology don't perform the analysis on behalf of the researcher (BeddallHill, et al., 2011). With the NVivo software that we used in the study, we realized that the software under qualitative methodology provides the researcher with a systematic or methodological framework only. It suggests ways to explore, give codes to data, and manage them (Beddall-Hill, et al., 2011). We believe the qualitative software package for data analysis is grounded on the same concepts as if you would like to examine data by hand (see attached appendix NVivo coding summary). The benefits of using the software in qualitative data analysis include the capability to store and handle the massive volume of data with many different sources, and the ability to share with others the coding frameworks of data collected. It means we can do some modifications; the coding designs can be measured and have the possibility to combine separate coding files (Beddall-Hill, et al., 2011). There are many programs available through the networking project website like the Computer Assisted Qualitative Data Analysis Software (CAQDAS).

Through this site, we were able to benefit some guidance to enable the team to decide on the most appropriate software to be used for data analysis under the qualitative methodology. It also provides updated reviews of the limitations and capabilities of the most frequently used software. For familiarization and experience purposes we tested both qualitative data analysis software, the most recognized and commonly used ATLAS.ti and NVivo. We discovered that both help store and manage data. Nevertheless, we opted for NVivo data analysis software as being the most appropriate to deal with a case study due to its ability to 
manage and store all collected data safely until the process of analysis begins (Beddall-Hill, et al., 2011). Also, we discovered that by using NVivo software as a storage facility we were able to reorganize the operations of data management appropriately (Beddall-Hill, et al., 2011). In the end, it helped to develop substantial and profound research. NVivo is easy to use and understand. Indeed, it is very user-friendly qualitative data analysis software. Ethical considerations are one of the most critical parts of the research. They are the norms of conduct that differentiate between what is acceptable and unacceptable. The fundamental reason is to avoid the forging of data. Hence, encourage research environment where accountability, level of trust, and mutual respect exist to be able to obtain knowledge and discover the truth of the matter.

Also, protect participants from all risks associated with the research (Grady, 2010). To deal effectively with ethical considerations in the research, we decided throughout the study to observe the following standards: Any participation must be voluntary, and the informed consent form was signed freely before they received the interview guide. Also, the participants have rights to stop contributing or complete withdrawal at any phase of the research without prejudice or prior notification. We avoided any offensive languages, the biased and other forms of unacceptable behavior throughout the research process. Data collected was safely protected to maintain anonymity, privacy and confidentiality of participants as per the University Ethical Policy (see appendix attached). We obtained the local written approval from the rector's office of the Théophile REYN Faculty Institute located in Lubumbashi, Haut-Katanga province. The Catholic Labor Chaplains Congregation runs this University.

\section{Results and Discussion of Findings}

Attribute of the Respondents: The respondents were a mix of fresh graduate students, assistant, priest, members of civil society, UN and Non-UN personnel, and unemployed youth both male and female altogether. For the interest of this study, participants were grouped into two categories. Assistant, priest, members of civil society, UN and non-UN personnel formed the group of the employed respondent category, while the fresh graduate students and other youths formed the second group of the unemployed respondent category.

First Phase: Interpretation of Results from Interviews and Focus Team Discussions: In this phase, we presented all gathered information that includes data analysis of verbal responses and their description in a clear layout. Also, this phrase reveals the results of all undertaken interviews and focus team discussions. The following are the questions we asked participants during the interviews:

A) What is the Impact of Autocratic Leadership in the DRC Security Sector? Most people we interviewed if not all of them unanimously confirmed that there is indeed leadership deficiency and some security concerns in the DRC. They commented that the use of autocratic leadership is most appropriate in the security sector (army and police) of the DRC. With this leadership style, commanders have much power over their soldiers; they are expected to make quick decisions in the least of time without asking other opinions. This leadership style develops the one-way communication approach as commanders make decisions alone; soldiers have minimal opportunity to suggest, even though their proposals would be in the sector's best interest (LFHE, 2016). However, using this leadership style in other areas mostly in civilian dominated industries may not be welcome, as it may be easily considered a dictatorship. This approach may lead to absenteeism and turnovers (LFHE, 2016). Finally, autocratic leadership should exclusively be applied in the security sector as personnel are trained to respect and execute given orders without questioning. This leadership style will help to restore discipline in the security sector of the DRC.

B) What is the Implication of the Democratic Leadership towards Establishing Stable State Institutions in the DRC? Most people we interviewed argued that democratic leaders are the ideal kind of leaders that the DRC needs for its transformation. These leaders make sure the group participate in decision making, and in the end, the leaders make the final say (LFHE, 2016). Unfortunately, the current regime in the DRC has chosen to weaken the system to manage the country freely, instead of establishing stable state institutions. This current system benefits specific groups of elites and abandons the rest of the people in extreme poverty (GAN Integrity, 2018). The existing state institutions which have the legitimate mandate to ensure state revenues are equitably distributed amongst the people to improve its well-being is fragile and corrupted (BTI, 2016). Because of the prevailing situation, the DRC economic growth is impacted negatively (Vanguard, 2018). 
Briefly, democratic leaders have the quality to establish stable state institutions to ensure sustainable development in the DRC. The stable state institutions should have the following structure and functions to be able to deliver efficiently and effectively: the legislative chamber accountable for endorsing state laws. The executive branch responsible for executing and managing the public policy approved by the parliamentary committee; the judicial branch is responsible for state law enforcement without interference or influence.

C) What is the Role of Transformational Leadership in the Fight against Corruption in the DRC? Transformational leaders empower others and expect good performance from the team members and on themselves as the model (LFHE, 2016). This leadership style helps leaders to achieve a high level of efficiency and commitment from team members. All interviewees confirmed that "The corruption kills the social fabric of the Congolese society" (Mansaray, 2009). Transformational leaders show the way and clear obstacles that could prevent the transformation from happening. Therefore, initiating the fight against corruption and good governance practices is a crucial task for these leaders. However, fighting corruption and restoring good governance in DRC requires the establishment of an effective and efficient anti-corruption body. Here again, the interviewees informed that it is sad to observe that in DRC while the anti-corruption body exists and so far, has done a great job to reveal to the authority with a comprehensive report of individuals suspected to be involved in massive corruption scandals.

But, decision-makers keep the reports in their drawers without any legal actions taken against those individuals, just because the same authority that has the constitutional power to reinforce the laws may also be involved in the scandals (Radiokapi, 2018). To deal with this activity, transformational leaders should establish and empower the anti-corruption unit ready to fight against issues of money laundering and embezzlement of public funds after enforcing both the laws and the judicial apparatus (Global security, 2018). This unit should have specified targets that include the control of possible suspected corruption case of state revenue, the control of expenditure at all levels of the state institutions, to monitor the requisitions and acquisitions of procurement for all government services on possible suspected corruption cases. Finally, the establishment of this anti-corruption unit should give to DRC a new approach to the control of expenditure practices, proper regulation and monitoring of the flows of natural resources.

D) What is the Relationship between Transactional Leadership and Poverty Reduction in the DRC? This leadership style as the name indicates "transactional" offers rewards that include compensation for best performance and applies punishment to those who underperformed (LFHE, 2016). Transactional leaders promote entrepreneurship to create employment to reduce poverty in the country. To deal effectively with poverty reduction in DRC, leaders must create more job opportunities for the people. The DRC economy should find ways to diversify and modernize its economy to be able to create employment that will help to reduce poverty in the country (UNCTAD, 2015). Considering DRC vast mineral wealth and massive natural resources, the DRC should look at developing vital sectors of the economy to be able to create more job opportunities for its people and gradually contribute towards reducing poverty. Many sectors can help in this undertaking. For example, the tourism industry has a lot of potential for job creation by rejuvenating most of the country's national parks (Kahuzi-Biega, Garamba, Maiko, Virunga, etc.) and many other unexploited touristic sites across the country. Agriculture sector with very fertile soil is another largest contributing sector with much potential for job creation (Global security, 2018).

So far approximately twenty per cent of land is reported to be in use (IAC, 2014). Meaning the remaining eighty per cent is vacant for job creation. Some interviewees also commented that referring to the initiatives of the former president Laurent Desire Kabila known "the Kanyama Kasese agricultural project." They believed that if the DRC could exploit all its lands for large agricultural projects, the production would be able to feed the whole African continent including the DRC, and most likely by now, the country would have eradicated the famine and made significant progress towards reducing poverty. Fisheries and livestock sector, with Tanganyika as the longest freshwater lake in the world, home to more than 300 species of fish that reside in its waters (Wikipedia, 2018); also, right grassing lands for millions of heads of cattle in the former Katanga, Kivus, Bas-Congo, and Orientale Provinces (IAC, 2014). Both sectors have significant potential for job creation and opportunity for poverty reduction. Also, the forestry sector, approximately $45 \%$ of rains forest in Africa belong to DRC, this is another excellent opportunity to create employment for many 
Congolese by attracting investors in the sector to deal with the business of timber intended for both local consumption and export (IAC, 2014).

E) What is the Relationship between Visionary Leadership and DRC Economic Development? To achieve long-term success, the DRC needs visionary leaders who have a convincing vision for the country; in other words, leaders who can see a bright future beyond today's challenges and uncertainties (Jeffrey, 2016). Also, modernizing different industries is paramount to strengthening the DRC economy. This diversity will help to stabilize the economy. Also, this approach will help the country to cease from being vulnerable to abrupt changes in commodities price (Global security, 2018). Consequently, visionary leaders should seek opportunities in various sectors as explained below:

Infrastructure and Electricity: The infrastructure sector has many opportunities for investments, for example, the construction of national highways to have a better road connecting across the country. With the purpose to facilitate road movement of goods and persons from the rural to urban areas and vice versa, the construction of roads to promote trades within the regions like SADC (Southern Africa), COMESA (East Africa) and ECCAS (Central Africa); - the creation of new or rehabilitation of old railway networks (ANAPI, 2018). Hydroelectric power of Inga alone contributes $42 \%$ of the total potential reserve of energy in the country. The DRC has the potential to produce one hundred Giga Watts per hour $(100 \mathrm{GW} / \mathrm{h})$. The following are some of the existing opportunities to boost the DRC economy: - the construction of regional power lines; first from Inga (DRC) crossing Angola, Namibia, and South Africa; second from Inga (DRC) to Nigeria (West Africa); and last from Inga (DRC) to Egypt (IAC, 2014). Ultimately, the DRC has the potential resources of hydroelectric plants to supply the electricity in all African countries. Unfortunately, the DRC lacks the necessary tools like stable institutions and good governance to materialize this profitable project (USAID, 2018).

Mining, Hydrocarbons, and Industrial Sectors: With a large reserve of minerals like gold, diamond, copper, cobalt, tin, tantalum Columbus, bauxite, iron, coal, manganese, etc. together with many other opportunities for oil, natural gas, and bitumen, textiles manufacturing company, tobacco, food, leather, wood, and paper (IAC, 2014). All these are opportunities that visionary leaders can develop to strengthen the DRC economy.

Second Phase: Interpretation of Results from Direct Observations, Participant Contributions and Reviewed Existing Documentation: Many interactions were conducted to get the opinions of some category of people to supplement the research findings. The purpose was to collect the inputs of some people who seem not comfortable with interviews but interested in the research topic, and they prefer to contribute informally. Also, we collected data from existing documentation. The following are amongst the issues discussed during the interactions:

Importance of Stable State Institutions in the DRC: Most people we interacted with have agreed that the current leadership is not doing enough to stabilize the state institutions. They prefer to operate with weak institutions to safeguard their interest. Today the legislative chamber supposedly to intervene on issues that are in people interest. Unfortunately, this chamber is found to be at the service of the executives and abandon their sole responsibility. The benefit of the people is no longer part of their agenda. Also, the judicial chamber lost its integrity by taking a side instead of being impartial; it is now at the service of the executives (BTI, 2016). Moreover, the judicial system has been instrumentalized and manipulated by those in power to serve their cause (BTI, 2016). The weakness of state institutions is an opportunity for some group of individuals to continue enriching themselves. Therefore, to end this era, it is crucial to change the current leadership and elect new leaders who can establish stable state institutions as to safeguard country economic development, ensure continuous improvement of people well-being, and provide safety and security of people and properties. There are several reports of human rights violations and sexual abuse against women. Also, maintain the DRC territorial integrity.

The Fight against Corruption in DRC: Corruption is continuously present in the DRC, it prevents seriously business environment and affects their operations in the country. Bribery in DRC pervades all state institutions and at all levels. It spreads throughout and consequently renders investment atmosphere in the country less competitive (GAN Integrity, 2018). The practice called "clientelism, favoritism and nepotism" has destroyed the spirit of fair competition in the country, mostly in public sectors and industries. It has deeply 
penetrated to such an extent that it obstructs all efforts to improve and strengthen transparency in the institutions (GAN Integrity, 2018). The malfunctioning of state institutions encouraged corruption to spread through, increase activities of the informal economy, and weaken the level of competitiveness. Also, businesses see bribery as standard practice and a way to solve the problem rapidly and continue the business (GAN Integrity, 2018). The level of corruption had been assessed to be very high within the DRC security services. It prevails among the DRC armed forces (FARDC) as well as in the Congolese national police (BTI, 2016). Also, corruption is found in the services offered by the public sector and presents significant danger mostly to foreign companies. Also, there is an increased level of petty corruption activities assessed as the result of a little salary scale paid to civil servants (Transparency International, 2014). Due to the degradation of payment condition, civil servants have no option other than getting involved in petty corruption activities as a mean for survival (BTI, 2016).

Poverty Reduction in DRC: Reports indicate that most of the Congolese citizen survive under one US dollar daily (UNDP, 2014b). If the DRC would like to fight against poverty, then it needs to diversify its economy by investing heavily on different sectors of the economy like agriculture, energy, infrastructure, mining, industrial, telecommunication, hydrocarbon sectors to mention only a few to promote wide-ranging economic development that will address poverty reduction and food insecurity in the country (USAID, 2018).

DRC Security Reform Outlook: The prospect for DRC to achieve sustainable peace and development is only possible if the security reform is taken very seriously and supported by the strong political will of the DRC leadership. The entire security services apparatus need a change, and they must be able to establish public order (police), protect borders against external intrusion (army). On the military side more is needed to create an organized and more unified army with the unique chain of command to ensure efficient security service is adequately provided across the country (EU-CSDP, 2014). Today, due to poor working conditions for military and police, they use weapons forcefully to steal money from people to survive (EU-CSDP, 2014). They are also exposed to exercise corruption by taking bribes. Human right organizations and NGOs accused the army of being unable to provide security to its citizen and its borders. Also, today the military is accused of being responsible for serious human rights violations across the country (OSF, 2018). The DRC army is still weak and could collapse very rapidly if tested with a significant threat. Therefore, it is paramount for the leadership to look urgently at reforming this critical sector since there would be no development if the country is not stable and at peace.

DRC Economic Development Outlook: The DRC has the potential to develop and become one of the leading economies in Africa if only it can address the instability around it political atmosphere. It has an enormous reserve of natural resources with thousands of metals and minerals, millions of hectares of arable soil, energy, and water (WBG, 2018). Unfortunately, the majority of Congolese citizen continues to live in extreme poverty and don't benefit from wealth (USAID, 2018).

Opportunities for Growth: Undoubtedly the commodities in DRC play an essential function for the survival of the economy. It means that the rise in commodity prices have a direct impact on the economy. Currently, looking at the increase of copper and cobalt prices, the government payment balance, currency exchange rate and reserves, and state revenues have the potential to improve. In the agriculture and industrial sectors, several studies on the practicability are ongoing to help the diversification plan since the current economy is heavily depending on mineral productions (AEO, 2018).

Threats to Growth: The safety and security in DRC remain a serious concern. The continued violence in some parts of the country (eastern and central provinces), threats to national peace and unity, and uncertainty on the political arena over the organization of the elections in December 2018 are all potential threats that could endanger the DRC economic growth. The devaluation of the national currency causing weak purchasing power for households is another concern that could ignite the current social crisis. The DRC has made little progress by catching up two seats in the world ranging from 184 to 182 out of a list of 190 countries, but the current business atmosphere in the country is still among the 10 worst states in the globe, thus a significant upgrade to improve the system is paramount (AEO, 2018). In summary, leadership deficiency is a significant concern in the DRC. These deficiencies encourage corruption, impunity, weaken 
state institutions, and eventually kill the country economic growth that would improve the well-being of the people, create more job opportunities and reduce poverty (USAID, 2014).

Discussion of Overall Findings: The following remarks could be drawn from the outcomes of the interviews, focus team discussions, direct observations, participant contributions, and documents. The research results disclosed that indeed the DRC is Africa second largest country with massive natural resources. This wealth provides many opportunities for the DRC to develop its economy and improve the well-being of the Congolese people. Unfortunately, leaders use those opportunities to enrich themselves while the people continue to live in extreme poverty. The Congolese citizen doesn't benefit from the revenue generated from the natural resources due to inequality, impunity, high level of corruption at all government levels, weak state institutions, leadership deficiency at all levels of the institutions, lack of political will, and corrupted justice and security services (USAID, 2014). These factors contribute immensely to the continued suffering of the Congolese people while enriching a small group of elites linked with the regime (GAN Integrity, 2018). They are the sources of unemployment, underemployment, criminality, and wars in many parts of the country (USAID, 2014). Also, this atmosphere reigns insecurity created by armed groups and militias. All these continue to fuel and destabilize the existing fragile security situation and ensure a complete deterioration of the well-being of the people.

\section{Summary, Conclusions and Recommendations}

Summary: The DRC needs a responsible leadership with a strategic vision and strong political will to transform the country. Once the head is committed to move forward in the right direction and play the role model, everybody will follow the same path. To turn the page, the DRC needs leaders who can empower state institutions to function without interference to guarantee sustainable economic and social development for generations. It is essential to know that people or politicians will pass through, but institutions will prevail. Therefore, having stable state institutions is critical to state continuity. This study informs the humanity that the DRC security sector requires immediate reform, and this can be achieved rapidly through a partnership with the international community (OSF, 2018). This partnership must be able to take robust measures to help improve the sector and eventually contribute to the development of the DRC. Concerning areas are military, police, and other security organs (EU-CSDP, 2014). The political will is considered at this point as the engine to make this machine moves forward and the security sector can achieve much-needed reform if leadership is determined to do so. The reason behind the failure for the DRC to provide an improvement to its army merely is due to lack of political will observed from its leaders (OSF, 2018).

Now, if leaders would like to engage seriously in the battle against corruption, then leaders need to demonstrate a political will to make changes by acting themselves as models and reinforce the applicability of the laws. Meaning taking to court all individuals involved in corruption scandals for a fair trial and executes the court decision without interference. Also, the anti-corruption body must be empowered by the laws to make sure the work it delivers is in the interest of the nation. This anti-corruption body must be independent, transparent, and impartial and preferably report directly to the head of state to avoid interference in the reporting channel. The DRC can achieve economic growth through diversification of its economy with good governance and committed leadership (Radiokapi, 2018). The country has many potentials that can also be exploited to feed the economy and cease from relying heavily on mining sector only which can cause significant damage to the economy in case of the collapse of commodity prices (AEO, 2018). Briefly, if the DRC could exploit in its fullness the sectors of the economy with responsible leadership and good governance in place, the country would be able to create more job opportunities and eventually reduce the poverty.

Conclusion: The study concludes that transformational leadership is imperative for any dramatic change to happen from the present chaotic situation toward the building of responsible state and subsequent development in the post-conflict environment. It is crucial to know that DRC leaders not only carry the responsibility to set a vision and guide people to work towards achieving the vision. But, it is their responsibility to motivate people for change to happen, to empower qualified personnel as managers to run the day to day activities toward rebuilding the DRC economy that suffered from many years of corruption and the devastating wars. Also, leaders need to set an environment that is conducive to unite the state with the 
society and establish social cohesion amongst Congolese people to cooperate to survive during the transition period and guarantee the prosperity of the DRC (LFHE, 2016).

To properly manage the transition period in the DRC from the situation of war to sustainable development and peace demands considerable and extra efforts from the DRC leaders. Also, to achieve long-term success, the DRC needs visionary leaders who are passionate and proactive about the transformation. For example, DRC leaders need to engage with all concerned partners either inside or outside the country to find better opportunities to implement the vision. Amongst the international partners, we have the Diaspora which is a significant workforce composed of professionals and experts. The regular auditing of the process is vital to ensure whether we achieved the priorities within the given time frame. The DRC leadership could mobilize and utilize well the Diaspora's expertise as this can help to reduce the high costs related to non-ordinary technical cooperation. It is essential to know that skilled members of the Diaspora returning home become genuine actors in the development of the country (OECD, 2014).

Recommendations: The following recommendations are imperative based on the findings from the two interviewed groups:

- Leadership emergence through fair, transparent, inclusive and democratic elections. People should be allowed to meticulously choose the right leaders at all level of government institutions.

- Visionary leadership: Leaders who will be committed to fight against impunity and restore good governance, empower the judicial apparatus, separate justice with politics to avoid institutional insecurity. Also, leaders who are ready to defend people interests, and most importantly leaders who will have the political will to improve the well-being, guarantee territorial integrity, the safety of people and their properties, and eventually, restore the dignity of the Congolese people. Briefly, to choose visionary leaders those who are determined to achieve long-term success for the DRC (Jeffrey, 2016).

- Also, the political will become more active if adequately supported by all the three branches of the institutions, executives, legislative and judiciary in the right directions. The executives can positively deliver to the expectation if the Justice system remains apolitical, neutral, and ready to defend the interest of the people without interference.

- Empowerment of stable state institutions: To recover from the chaotic situation in DRC, democratic leaders should establish and empower stable state institutions. Those institutions should have the following structure to be able to deliver effectively: The legislative chamber which will be accountable for endorsing state laws without interference and influence whatsoever, this chamber must be impartial and operates independently. Also, the chamber should have the legal right to approve, disapprove or amend necessary bills to enable the government to operate. The executive branch must be responsible for executing and managing the public policy endorsed by the legislative chamber. It is in this chamber where the government belongs. The judicial branch must be accountable for explaining the content of the constitution and the laws of the Republic (DRC) and applying their understandings to solve possible disagreements (NCSL, 2018).

- The DRC needs to revitalize it's, armed and police forces, the size of its armed forces must have realistic and verifiable figures. Therefore, improving their working and living conditions together with their appropriate training are crucial elements to ensure they provide effective, efficient and sustainable security services throughout the country. Also, the revitalization process should consist of retiring officers who reached fifty years of age and settling all their dues before separation. So that newly recruited soldiers can fill the gap and eventually rejuvenate the armed forces. Also, the recruitment process should consider the educational background of candidates. Finally, the purpose of this reform is to establish an active, disciplined and patriotic force ready to serve the nation faithfully (EU-CSDP, 2014).

- Poverty reduction: To reduce poverty, in the short-term transactional leadership plays a significant role to build good governance spirit to manage and distribute the revenues equitably by rewarding personnel for excellent performance and punish those who underperformed. But, in the long-term, this approach will face severe limitations and may lead to high staff turnover (LFHE, 2016). Therefore, the ability for DRC leaders to switch from one leadership to another to cope with the reality is crucial. The transformational leadership should take over from the transactional leadership 
to ensure good sustainable governance and explore other initiatives that can bring new value (LFHE, 2016). The research also recommends to DRC decision-makers to promote the policy of "exporting more and importing less" since the DRC economic growth depends on its production, this approach will strengthen the financial autonomy and render it less vulnerable to outside threats.

Implications and Contribution to knowledge: The research has developed a much more user-friendly formula that summarizes this study. The formula fits all contexts from state institutions to public or private Organizations. Symbolically, VISION $=\mathrm{CL}+\mathrm{PW}+$ SSI. Where $\mathbf{C L}=$ Committed Leadership; PW= Political Will, SSI= Stable State Institutions. Conceptually, no country can ever achieve its vision without the support of these three major elements. One needs a committed leadership in place to set the idea, and we can reach the milestones toward achieving this vision with the support of the political will and stable state institutions. In other words, the political will becomes more active if fully supported in the right directions by all the three branches of the institutions' executives, legislative and judiciary (NCSL, 2018). The research has further revealed that managing people expectations in the country that needs significant reform like the DRC requires a strong political will to support the vision (Raile et al., 2018). Some groups of elites who have long benefitted from the chaos may not readily welcome the changes; they will try to interfere with the changes.

Knowing the challenges ahead managing people expectations in the post-conflict environment with many modifications to handle requires several factors that need to be observed like regular interaction mechanisms between leader and stakeholders to strengthen ties, proper consultation, forums and dialogues, listening to people views and enable their representatives to take part actively in the decision-making process (Karten, 2013). Fixing short-term priorities without losing track on the long-term plan is essential to build trust from the partners and more importantly create hope in people for a bright future. Transform the country with the participation of major stakeholders including the civil society, NGOs, and media. Like any other projects, the method may face challenges during the execution and may require some adjustments, negotiations, even additional fund commitment; to deal with it requires the leadership to be equipped with some attributes to be able to adapt the context when variables arise. To be able to achieve good governance, leadership must ensure that the country has a robust and impartial justice apparatus to fully support the transformation efforts. This Justice must be apolitical, and all its members must not have allegiance to any political party to maintain its neutrality.

In a post-conflict environment, people's expectations are many and urgent. After setting the long-term vision and understanding of people expectations. Thus, leaders need to break down the concept into short-term actions and be able to mobilize resources to achieve milestones so that people build trust as they see change happening towards improving their conditions in the least period. Remember in the post-conflict environment people are exhausted and out of patience and cannot afford to wait for results to happen in ten years. Thus, Initiatives for development at all levels of the institutions in support of the vision must be encouraged. A divided society exists because of the war after many atrocities that have been committed. In a post-conflict environment issues related to ethnic hatred, divisions, Isolation, and mistrust amongst the people could even get worse if leadership does not take urgently a holistic approach to address the causes (SAHO, 2017). To eradicate these flaws, leaders should create an organ in charge of unity or truth and reconciliation to foster a system of regular communication and sincere dialogue between communities to resolve differences and promote integration, while preaching forgiveness between populations and not revenge. Put aside their differences and join strengths to make the country more prosperous (SAHO, 2017). Leaders cannot achieve sustainable peace if the causes of the war are not adequately addressed to avoid reoccurrence of the war.

Limitations and Suggestions for Future Studies: The research encountered some challenges during the process such as political criticism. Some people even rejected the request to conduct this academic research within their organization citing the subject of being sensitive with the potential to have political repercussions. Though attracted by the relevance of the topic, some people were still afraid to speak out publicly of fear of being accused of criticizing the current regime or merely being against the system, and most likely end up being arbitrarily arrested by security organs. Nevertheless, these people would instead prefer to speak at closed doors. Efforts were made to ensure anonymity in all information they provided as per University ethical policy (see appendix attached). Also, some unemployed youths had a negative attitude 
not because they were not interested in the subject, but because they were desperate for their stagnant unemployment status. These youths were pessimistic as they have no hope for the possible transformation of their well-being soon.

It was hard to convince them to contribute to the research. Nevertheless, we overcame the challenges and managed to get them on board, and they helped tremendously. The answers we obtained during the interviews were genuine. In the context of performance in the post-conflict state, further studies to determine their importance in chronological order would reveal new approach on which performance leaders can start implementing even with limited resources as we may not be financially healthier to undertake all the five performances at a go. Knowing that each performance requires considerable investment, hence planning is essential to figure out which performance to execute first. Once again, during the post-conflict environment needs are many and pressing, ergo knowing which one comes first at each point in time will help leaders to prioritize resources on most important projects, and then move progressively to the next one. Instead of embracing all at once, run out of funds and stop halfway without achieving intended results. Also, this approach will help leaders to monitor the projects easily and ensure its efficiency. Being interconnected, completing the first task successfully, will pave the way to the next functions.

\section{References}

African Economic Outlook. (2018). Democratic Republic of Congo Economic Outlook.

Awolusi, O. D. \& Atiku, O. S. (2019). Business Process Re-Engineering and Profitability in the Nigerian Oil and Gas Industry: The Mediating Influence of Operational Performance, Information Management and Business Review, 11(3), 13-26.

Awolusi, O. D. (2019). Human Capital Development and Economic Growth in BRICS Countries: Controlling for Country Differences, Journal of Economics and Behavioral Studies, 11(4), 1-17.

Beddall-Hill, N., Jabbar, A. \& Shehri, S. (2011). Social Mobile Devices as Tools for Qualitative Research in Education: iPhones and iPads in Ethnography, Interviewing, and Design-Based Research. Journal of the Research Center for Educational Technology, 7(1), 67-89.

Bass, B. M. (1990). From transactional to transformational leadership: Learning to share the vision. Organizational Dynamics, 2(2), 19-31.

Bertelsmann Transformation Index (BTI). (2016). Bertelsmann Foundation: Transformation Index.

Burnley, C. $(1978,2011)$. Natural Resources Conflict in the Democratic Republic of the Congo: A Question of Governance? Sustainable Development Law \& Policy, 12(1), 7-53.

Carter, N., Bryant-Lukosius, D., DiCenso, A., Blythe, J. \& Neville, A. J. (2014). The use of triangulation in qualitative research.

Chandler, C. I. R., Reynolds, J., Palmer, J. J. \& Hutchinson, E. (2013). ACT Consortium Guidance: Qualitative Methods for International Health Intervention Research.

Clementine, B. (2011). Sustainable Development Law \& Policy, 12(1), 23-34

European Union. (2014). Common Security and Defense Policy.

Global security. (2018). DR Congo-Economy.

Grady, C. (2010). Do IRBs protect human research participants? JAMA: The Journal of the American Medical Association, 304(10), 1122-1123.

International Monetary Fund. (2018). List of Countries by Projected GDP per capita.

Iqbal, N., Anwar, S. \& Haider, N. (2015). Effect of Leadership Style on Employee Performance. Arabian J Bus Manag Review, 5(1), 146-154.

Ital Africa Central. (2014) Democratic Republic of Congo Economy.

GAN Integrity Inc. (2018). DR Congo Corruption Report.

Karten, N. (2013). Managing expectations: working with people who want more, better, faster, Sooner.

Kemps. (2018). Available at https://www.kemps.com/meet-us/careers/accessed: 22/03/18.

Lacono, J., Brown, A. \& Holtham, C. (2009). Research Methods - a Case Example of Participant Observation. The Electronic Journal of Business Research Methods, 7(1), 39-46.

LFHE. (2016). Leadership Foundation for Higher Education.

Management Study HQ. (2018). Available at https://www.managementstudyhq.com/types-ofleadership.html, accessed: 23/03/18 
DRC National Agency for the Promotion of Investments, ANAPI. (2018). Available at https://www.investindrc.cd/en/sectors/infrastructure, accessed: 07/07/18

NCSL. (2018). National Conference of States Legislatures.

Raile Eric \& Post, Lori. (2018). Analysis and action: The political will and public will approach. Action Research.

OECD Report. (2014). On the Implementation of the OECD Strategy on Development. Meeting of the OECD Council at Ministerial Level Paris, 6-7.

Open Society Foundations. (2018). The Democratic Republic of Congo: Taking a Stand on Security Sector Reform.

Pavlov's thoughts. (2010). Available at https://pavlos.geekhost.org/2010/02/24/sources-of-leadership/, accessed: 22/03/18

Peter Sorie Mansaray. (2009). Combating Corruption in Sierra Leone.

Radio Okapi News. (2018). RDC: le Parquet général de la République ouvre une information judiciaire sur le passeport de Moïse Katumbi.

Radio Okapi News. (2018). Matata Ponyo prône la diversification et l'industrialisation de l'économie de la RDC.

Reuters. (2018). World News, available at https://www.reuters.com/article/us-congo-violence/congoviolence-forces-over-22000-to-flee-to-uganda-idUSKCN1FX1WA, accessed: 13/04/18.

Robert, L. \& Brennan. (2010). Generalizability Theory and Classical Test Theory, Applied Measurement in Education, 24(1), 1-21.

SAHO. (2017). South African History Online, available at: https://www.sahistory.org.za/topic/truth-andreconciliation-commission-trc, accessed: 17/08/18

Scott Jeffrey. (2016). 10 Attributes of Visionary Leadership for Change Agents and Outperforming Entrepreneurs.

Surbhi, S. \& Sood. (2016). Key Differences.

Thompson, J. (2011). Is Nonverbal Communication a Numbers Game? | Psychology Today.

Transparency International. (2018). Available at https://www.transparency.org/what-is-corruption\#define, accessed: $20 / 05 / 18$

UNCTAD. (2015). Trade and Poverty Alleviation in Africa: The Role of Inclusive Structural Transformation.

UNDP (United Nations Development Program). (2014b). Human Development Report 2014. Sustaining Human Progress: Reducing Vulnerabilities and Building Resilience'. New York: United Nations Development Program.

USAID. (2014). Country Development Cooperation Strategy, Democratic Republic of the Congo.

USAID. (2018). The Democratic Republic of the Congo: economic growth fact sheet.

USIP. (2011). Special Report, available at https://www.usip.org/sites/default/files/SR_289.pdf, accessed: $18 / 03 / 18$

Vanguard. (2018). Weak state institutions, strong individuals.

Wilson Learning Worldwide Inc. (2018). Available at http://www.wilsonlearning.com/wlw/leadership/lapproach/form, accessed: 22/3/18

Wikipedia. (2018). Lake Tanganyika, available at https://en.wikipedia.org/wiki/Lake_Tanganyika, accessed: $24 / 06 / 18$

World Bank Group. (2018). The Democratic Republic of Congo. 